\title{
Effects of the Growth Retardant Triadimefon on the Ex vitro Establishment of Gladiolus (Gladiolus grandiflorus L.) cv. Vinks Glory
}

\author{
A. Sheena and V.L. Sheela* \\ Department of Pomology and Floriculture, College of Agriculture, Vellayani \\ P.O.: Thiruvananthapuram District, Kerala State, India
}

Key words: Gladiolus, Triazole, Micropropagation,Triadimefon, Acclimatization

\begin{abstract}
Triadimefon, a triazole compound increased survival per cent of micropropagated Gladiolus (Gladiolus grandiflorus L.) plantlets. Application of triadimefon caused a retarding effect on height of the plant $(14.86 \mathrm{~cm})$ compared to the untreated plants one month after planting to ex vitro conditions. Triazole application increased root number of the plants. Plants treated with triazole showed delayed leaf production interval of 10.45 and 14.48 days for first and second leaves, respectively. Triazole treated plants exhibited a lower stomatal conductance which indicated the reduced water loss from the leaves. Leaf area index was high for untreated plants(1.08) compared to treated plants.
\end{abstract}

\section{Introduction}

Gladiolus (Gladiolus grandiflorus L.), a member of Iridaceae is one of the important bulbous ornamental plants. It is a high value cut flower crop mainly grown for its elegant cut spikes. It is popular in many parts of the world due to the beauty and vase life of the inflorescence. The genus Gladiolus includes 180 species with more than 10,000 cultivars (Sinha and Roy 2002). Dormancy of the cormels coupled with diseases in storage as well as under field condition creates problems in multiplication of planting material. Tissue culture tech-nique, which enables large scale production of disease free plants, will help in overcoming scarcity of planting material of gladiolus. The technique is based on in vitro culture of various explants capable of regeneration on suitable media as reported by several researchers (Ziv et al. 1970, Hussey 1977, Bajaj et al.

*Author for correspondence. <sheela_jayagopan@yahoo.com>. 
1983, Misra and Singh 1999, Hussain et al. 2001, Pathania et al. 2001, Priyakumari and Sheela 2005, Aftab et al. 2008, Kumar et al. 2010).

The technique for micropropagation in Gladiolus is standardized. However, problems are being encountered in $e x$ vitro establishment of plantlets. Hardening and ex vitro establishment of plantlets are the most difficult stages in the micropropagation of gladiolus (Razdan 2003). The benefit of any micropropagation system can only be fully realized by the successful transfer of plantlets from tissue culture vessels to the ambient conditions found ex vitro. Most species grown in vitro require an acclimatization process in order to ensure that sufficient number of plants survive and grow vigorously when transferred to soil (Hazarika 2003). Normal development of micropropagated plantlets during acclimatization and hardening stage is mandatory to ensure a high percentage of survival after transplanting to ex vitro conditions. Acclimatizing, hardening-off, or conditioning plantlets from the in vitro to the ambient environment can be a challenge that may result in death or damage to a large percentage of micropropagated plants (Preece 2010). Micropropagation on a large scale can be successful only when plantlets after transfer from culture to soil show high survival rates. Standardizing the techniques for ex vitro establishment of tissue culture plantlets of gladiolus will streamline the supply of elite planting material in sufficient number for large-scale cultivation.

The present study was carried out to investigate the effect of triazole compound on the ex vitro establishment of micropropagated gladiolus plantlets.

\section{Materials and Methods}

In vitro rooted plantlets of Gladiolus (Gladiolus grandiflorus L.) cv. Vinks Glory were used for the experiment. The plantlets were produced based on the following protocol. Cormels collected from field grown gladiolus plants were dehusked and immersed in 1000 times diluted Labolene solution for 30 minutes. It is washed thoroughly in running tap water for five minutes and then in distilled water. These cormels were surface sterilized with 0.08 per cent $\mathrm{HgCl}_{2}$ for ten min with intermittent shaking inside a laminar air flow. The solution is drained and cormels are washed four to five times with sterile distilled water. Cormels were inoculated in MS with BA $2.00 \mathrm{mg} / \mathrm{l}$ and NAA $0.50 \mathrm{mg} / 1$ and multiple shoot initiation is obtained. After two - three subcultures, individual shoots measuring 2.50 - $3.50 \mathrm{~cm}$ length excised from the shoot proliferating cultures are subjected to in vitro rooting in IBA $2.00 \mathrm{mg} / \mathrm{l}$. 
The experiment was laid out in completely randomized design with six replications.

Solutions of 4 and $8 \mathrm{mg} / \mathrm{l}$ of a triazole compound, Triadimefon were prepared and applied to the potting media.

The culture vessels with in vitro rooted plantlets were opened and plantlets were taken out using a pair of sterilized forceps. The agar adhering to the roots was completely removed by thorough washing under running tap water and then washed in distilled water. During all these processes, care was taken for not damaging the roots. The plantlets were subjected to a fungicide treatment in 0.1 per cent Indofil (Dithane M$45)$ by dipping in it for a period of 10 minutes. These plantlets were planted in disposable cups filled with sterilized potting media and subjected to different treatments. The plants were kept inside a humidity chamber covered with polythene sheets of 350 gauge thickness for 30 days.

After 15 days of planting the plantlets were irrigated twice a week with 0.1 MS solution. Humidity inside the chamber was adjusted by lifting the polythene sheet and plantlets were gradually exposed to sunlight. After the observation period, some of the plants were transferred to pots and placed outside.

Survival of the plantlets was observed at fortnightly and they were observed for further study. Height of the plant was measured from the collar region to the tip and the mean length was expressed in centimeter. The total number of fully opened leaves developed per plantlet was counted and the mean value was expressed. The total number of roots per plantlet was counted and the mean value was calculated.

Number of leaves produced were noted at weekly interval to find out phyllochron. Time taken for emergence of first and second ex vitro leaves was expressed in days.

Stomatal resistance of individual plants was recorded using a Porometer (Delta T devices-Cambridge-UK) at fortnightly during 10 to 12 a.m.

$$
\text { Stomatal conductance }=\frac{1}{\text { Stomatal resistance }}
$$

Stomatal conductance was expressed in $\mathrm{cm} / \mathrm{s}$.

Leaf area index was calculated by employing the formula of Rajeevan et al. (1992).

Leaf area $=$ Length of leaf $\times$ breadth of leaf $\times 0.635+12.9$. 


$$
\text { Leaf area index }=\frac{\text { Leaf area per plant }}{\text { Area occupied per plant }}
$$

\section{Results and Discussion}

Efficient commercial micropropagation depends on rapid and extensive proliferation along with the use of large scale cultures for the multiplication phase. But normal plant development during ex vitro establishment stage is very much essential to ensure a high per cent of survival after field planting (Preece and Sutter 1991). Plantlets that have grown in vitro have been continuously exposed to a unique microenvironment that has been selected to provide minimal stress and optimum conditions for plant multiplication. These conditions contribute a culture induced phenotype that cannot survive the environmental conditions when directly placed in greenhouse or field (Hazarika 2003). Transfer of in vitro plantlets to ex vitro conditions is the most critical stage in the widespread use of micropropagation. To promote ex vitro survival and physiological competence, especially to protect the plants from various stresses and to encourage autotrophy, a transitional environment is needed during the acclimatization phase. Manipulating the acclimatization conditions prior to or upon transplanting usually reduced losses (Huyelenbroeck and Debergh 1986, Preece and Sutter 1991, Desjardins 1995) however, at additional cost to the producers.

Triadimefon [1-(4-chlorophenoxy)-3, 3-dimethyl-1H-(1, 2, 4-triazol1-yl) butan-2-one], a triazole compound which is a plant growth retardant, was tried in the ex vitro establishment study. Survival per cent was calculated at fortnightly interval. Plantlets treated with triazole at a concentration of $4 \mathrm{mg} / 1$ showed a higher survival rate of 73.83 per cent 15 days after planting, whereas one month after planting, individuals treated with $8 \mathrm{mg} / \mathrm{l}$ showed 55.83 per cent survival followed by $4 \mathrm{mg} / \mathrm{l}$ with 54.16 per cent survival. Untreated plants recorded 47.50 per cent survival after one month of planting. It is evident that triazole treatment recorded higher survival per cent than untreated plants. Davis et al. (1986) obtained better survival of ornamental plants treated with triazole while transplanting to greenhouse. Samasya (2000) also obtained similar results during the ex vitro establishment stage of micropropagated orchids.

Leaf number, plant height, root number, leaf production interval (phyllochron), stomatal conductance and leaf area index was given in Table 1. 
Table 1. Leaf number, plant height, root number, leaf production interval (phyllochron), stomatal conductance and leaf area index of triadimefon treated micropropagated gladiolus plantlets.

\begin{tabular}{|c|c|c|c|c|c|c|c|c|c|c|c|}
\hline \multirow[t]{2}{*}{$\begin{array}{l}\text { Treat- } \\
\text { ment }\end{array}$} & \multicolumn{2}{|c|}{$\begin{array}{c}\text { Leaf } \\
\text { number }\end{array}$} & \multicolumn{2}{|c|}{$\begin{array}{l}\text { Plant height } \\
(\mathrm{cm})\end{array}$} & \multicolumn{2}{|c|}{$\begin{array}{c}\text { Root } \\
\text { number }\end{array}$} & \multicolumn{2}{|c|}{$\begin{array}{l}\text { Phyllochron } \\
\text { (days) }\end{array}$} & \multicolumn{2}{|c|}{$\begin{array}{c}\text { Stomatal } \\
\text { conductance } \\
(\mathrm{cm} / \mathrm{s})\end{array}$} & \multirow{2}{*}{$\begin{array}{c}\begin{array}{c}\text { Leaf } \\
\text { area } \\
\text { index }\end{array} \\
30 \\
\text { DAP }\end{array}$} \\
\hline & $\begin{array}{c}15 \\
\text { DAP }\end{array}$ & $\begin{array}{c}30 \\
\text { DAP }\end{array}$ & $\begin{array}{c}15 \\
\text { DAP }\end{array}$ & $\begin{array}{c}30 \\
\text { DAP }\end{array}$ & $\begin{array}{c}15 \\
\text { DAP }\end{array}$ & $\begin{array}{c}30 \\
\text { DAP }\end{array}$ & $\begin{array}{l}\text { First } \\
\text { leaf }\end{array}$ & $\begin{array}{c}\text { Second } \\
\text { leaf }\end{array}$ & $\begin{array}{c}15 \\
\text { DAP }\end{array}$ & $\begin{array}{c}30 \\
\text { DAP }\end{array}$ & \\
\hline \multicolumn{12}{|l|}{ Triazole } \\
\hline $\mathrm{B}_{0}$ & 4.88 & 5.68 & 12.58 & 15.81 & 5.05 & 8.23 & 9.35 & 13.30 & 0.79 & 0.20 & 1.08 \\
\hline $\mathrm{B}_{1}$ & 4.70 & 5.60 & 12.54 & 14.87 & 5.53 & 9.18 & 10.35 & 14.15 & 0.73 & 0.15 & 1.00 \\
\hline $\mathrm{B}_{2}$ & 4.50 & 5.37 & 12.49 & 14.86 & 5.68 & 9.38 & 10.45 & 14.48 & 0.62 & 0.10 & 0.94 \\
\hline SE & 0.20 & 0.23 & 0.23 & 0.28 & 0.24 & 0.25 & 0.33 & 0.25 & 0.02 & 0.01 & 0.01 \\
\hline $\mathrm{CD}(0.05)$ & NS & NS & NS & 0.79 & NS & 0.71 & 0.92 & 0.70 & 0.05 & 0.02 & 0.04 \\
\hline
\end{tabular}

Height of the plant was found to be affected significantly by triazole treatment one month after planting. Untreated plants recorded maximum plant height of $15.81 \mathrm{~cm}$ while plants treated with triazole at $8 \mathrm{mg} / \mathrm{l}$ recorded minimum plant height $(14.86 \mathrm{~cm})$. This shows the retarding effect of triazoles. Similar result was obtained by Samasya (2000) in micropropagated orchids. This is due to the effect of triazoles on isopropanoid pathway which produces gibberellin responsible for elongation of plants. Triazoles block the isopropanoid pathway and thus affect gibberellin biosynthesis (Graebe 1987), which in turn led to reduction in plant height. The reduced plant height due to the inhibitory action of triazole on gibberellic acid biosynthesis was also reported by Hazarika (2003). In the present study plants with greater height tended to be lanky with long and narrow leaves that are difficult to establish.

One month after planting, plants subjected to triazole at $8 \mathrm{mg} / \mathrm{l}$ showed highest root number (9.38) while untreated plants showed lowest root number (8.23). Similar results were obtained in micropropagated Prunus serotina by Eliasson et al. (1994) and in micropropagated sugarcane by Dhaliwal et al. (1997). This might be due to the shift in partitioning of assimilates from the leaves to the roots due to the action of triazoles (Steffens et al. 1985).

Triazole treatment affected leaf emergence of the plantlets during the ex vitro establishment stage. In plants treated with triazole at $8 \mathrm{mg} / \mathrm{l}$, the first leaf emerged after 10.45 days and second leaf after 14.48 days of transplanting. At the same time untreated plants took 9.35 and 13.30 days for emergence of first and second leaf, respectively. From this it is clear that triazole treated plants showed a higher leaf production interval (phyllochron) compared to that of untreated plants. This might be due to the growth retarding action of triazoles. In accordance with 
this, Tari (2003) reported inhibition of primary leaf expansion in bean seedlings by triazole treatment. Ziv et al. (2003) also reported inhibition of leaf expansion in vitro as a result of addition of triazoles to the culture media.

Triazole treatment influenced the stomatal conductance significantly. After the first fortnight, plants treated with triazole at $8 \mathrm{mg} / \mathrm{l}$ showed low stomatal conductance of $0.62 \mathrm{~cm} / \mathrm{s}$ followed by $4 \mathrm{mg} / \mathrm{l}$ with a value of $0.73 \mathrm{~cm} / \mathrm{s}$ whereas untreated plants exhibited a higher stomatal conductance of $0.79 \mathrm{~cm} / \mathrm{s}$. The same trend was seen one month after planting even if the values ranged between 0.10 and $0.20 \mathrm{~cm} / \mathrm{s}$. This indicates that triazole decreases the stomatal conductance. Similar results were obtained by Bishnoi et al. (1994). Low stomatal conductance indicates reduced water loss and it is important in the maintenance of plant water status. High rate of water loss incurred by in vitro grown plants imposed severe limitation in acclimatization. But application of triazole during ex vitro establishment helped to overcome this limitation by reducing the water loss from the plant. This was in accordance with the findings of Hazarika et al. (2002). According to Tari (2003) the decrease in stomatal conductance was due to the reduced water loss from triazole treated leaves which in turn was caused by the reduced leaf area due to the growth retarding effect of triazole.

In the present study stomatal conductance was found to be higher in the first fortnight and it gradually decreased by the end of second fortnight. This might be due to the leaves of in vitro grown plants showed open stomata and collapsed guard cells, while acclimatized leaves presented closed stomata as well as decreased stomatal density and aperture (Romano and Martins-Loucao 2003).

In the present study, untreated plants showed higher leaf area index of 1.08 followed by a reduction $(0.94)$ by the triazole treated plants. This is contradictory to the findings of Dhaliwal et al. (1997) and Rajendiran and Ramanujan (2003). The reduced leaf area index might be due to the reduction in plant height and leaf size.

Survival rate obtained in this study was moderate and the initial growth rate was slow. The shift in partition of assimilates from leaves to the ex vitro developed corm might be the reason for the initial slow growth of the plantlets. Production of cormels in vitro and planting of these cormels may have helped to overcome this situation. Future work should be oriented in this direction. 


\section{References}

Aftab F, Alam M and Afrasiab H (2008) In vitro shoot multiplication and callus induction in Gladiolus hybridus Hort. Pak. J. Bot. 40(2): 517-522.

Bajaj YPS, Sidhu MMS and Gill APS (1983) Some factors affecting the in vitro propagation of gladiolus. Scientia Hort. 18: 265-275.

Bishoni NR, Karwasra RS, Gupta SN and Bainiwal CR (1994) Influence of growth retardants on water relations and yield of bajra under rainfed conditions. Indian J. Pl. Physiol. 37: 73-75.

Davis TD, Walser RH, Sorenson K and Sankhla N (1986) Rooting and subsequent growth of cuttings treated with paclobutrazol. J. Am. Soc. Hort. Sci. 109: 876-886.

Desjardins $Y$ (1995) Factors affecting $\mathrm{CO}_{2}$ fixation in striving to optimise photoautotrophy in micropropagated plants. Pl. Tissue Cult. Biotech. 1: 13-25

Dhaliwal RK, Malik CP, Gosal SS and Dhaliwal LS (1997) Studies on hardening of micropropagated sugarcane (Saccharum officinarum L.) plantlets. I. Root and shoot parameters. Ann. Biol. 13: 21-25.

Eliasson MK, Beyl CA and Barker PA (1994.) In vitro responses and acclimatization of Prunus serotina with paclobutrazol. J. Pl. Growth Regulation 13: 137-142.

Graebe JE (1987) Gibberellin biosynthesis and control. A. Rev. Pl. Physiol. 381: 419465.

Hazarika BN (2003) Acclimatization of tissue cultured plants. Curr. Sci. 85: 17041712.

Hazarika BN, Parthasarathy VA and Nagaraju V (2002) Anatomical variation in citrus leaves from in vitro and greenhouse plants: Scanning electron microscopic studies. Indian J. Hort. 59: 243-246.

Hussain IA, Rashid MH and Quraishi A (2001) In vitro multiplication of Gladiolus. Plant Tiss. Cult. 11: 121-126.

Hussey G (1977) In vitro propagation of gladiolus by precocious axillary shoot formation. Scientia Hort. 6: 287-296.

Huylenbroeck JMV and Debergh PC (1986) Physiological aspects of micropropagated plantlets. Plant Tissue Cult. Biotech. 23: 136-141.

Kumar A, Palni LMS and Sood A (2010) Factors affecting in vitro formation of cormlets in Gladiolus hybridus Hort. and their field performance. Acta Physiol. Plant. DOI: 10.1007/s11738-010-0574-y.

Misra S and Singh R (1999) In vitro propagation of gladiolus cv. American Beauty. J. Ornamental Hort. 2: 67-70.

Pathania NS, Misra RL and Raghava SPS (2001) Precocious shoot proliferation and microcorm production in gladiolus through tissue culture. J. Ornamental Hort. 4: 69-73.

Preece JE (2010) Acclimatization of Plantlets from In vitro to the Ambient Environment. Encyclopedia of Industrial Biotechnology: Bioprocess, Bioseparation, and Cell Technology. DOI : 10.1002/9780470054581.eib593. 
Preece JE and Sutter E (1991) Acclimatization of micropropagated plants to the greenhouse and field. Micropropagation technology and applications. (eds Debergh PC, Zimmerman RH) Kluwer academic publishers. Dordrecht, The Netherlands, pp. 245-251.

Priyakumari I and Sheela VL (2005) Micropropagation of gladiolus cv. 'Peach Blossom' through enhanced release of axillary buds. J. Trop. Agric. 43(1-2): 47-50.

Rajeevan PK, Ravidas L and Krishnan S (1992) Estimation of leaf area in gladiolus from linear parameters. S. Indian Hort. 40: 239-241.

Rajendiran K and Ramanujam MP (2003) Alleviation of ultraviolet-B radiationinduced growth inhibition of greengram by triadimefon. Biologia P1. 46: 621-624

Razdan MK (2003) Introduction to plant tissue culture. Oxford and IBH Publishing Co. Pvt. Ltd. New Delhi, p. 375.

Romano A and Martins-Loucao MA (2003) Water loss and morphological modifications in leaves during acclimatization of cork oak micropropagated plantlets. Acta Hort. 616: 439-442.

Samasya KS (2000) Physiological aspects of ex vitro establishment of tissue cultured orchid (Dendrobium sp. var. Sonia-17) plantlets. M.Sc. (Ag.) thesis, Kerala Agricultural University, Thrissur, p. 139.

Sinha $\mathbf{P}$ and Roy SK (2002). Plant regeneration through in vitro cormel formation from callus culture of Gladiolus primulinus Baker. Plant Tiss. Cult. 12: 139-145.

Steffens GL, Wang SY, Faust M and Byun JK (1985) Controlling plant growth via gibberellin biosynthesis system. Physiol. Plant. 63: 163-168

Tari L (2003) Abaxial and adaxial stomatal density, stomatal conductance and water status of bean primary leaves as affected by Paclobutrazol. Biologia Plant 47: 215220.

Ziv M, Chen J and Vishnevetsky J (2003) Propagation of plants in bioreactors: prospects and limitations. Acta Hort. 616: 85-92.

Ziv M, Halevy AH and Shilo R (1970) Organs and plantlet regeneration of gladiolus through tissue culture. Ann. Bot. 34: 671-676. 